\title{
Strongly positive tissue transglutaminase antibody assays without celiac disease
}

\author{
Hugh James Freeman MD
}

HJ Freeman. Strongly positive tissue transglutaminase antibody assays without celiac disease. Can J Gastroenterol 2004;18(1):25-28.

Celiac disease is a small bowel disorder characterized by flattened villi and crypt hyperplasia, often with malabsorption. Improvement occurs with a gluten-free diet. Sensitive and specific assays (eg, immunoglobulin A antibodies to tissue transglutaminase [tTG]) that can be quantified appear to be valuable tools for population screening studies. In addition, their use is expanding widely in the clinical practice arena, being employed as a method of case finding. In this evaluation, clinical use of a commercially available test kit was explored. Of 1330 samples submitted to our hospital laboratory by physicians in British Columbia, Alberta and the Yukon Territory (from 1999 to 2003, inclusive), 96 patients (7\%) had increased values (normal range greater than 20 units) and markedly increased levels greater than 100 units were detected in 36 patients (3\%). Of these, 14 patients (almost 40\%) were referred to gastroenterologists in our hospital and all 14 had small intestinal biopsies. Of these, three patients (more than 20\%) did not have celiac disease. Two had normal small bowel biopsies and one had unclassified sprue or 'spruelike'intestinal disease that failed to respond to a gluten-free diet. The other 11 had biopsy-defined celiac disease. While the tTG assay may be a useful predictor of celiac disease, small intestinal biopsy is still required to confirm the diagnosis. In clinical practice, even strongly positive tTG results are not specific in individual patients, do not necessarily correlate with the degree of severity of biopsy change and, as a result, are also unlikely to be useful for monitoring diet compliance.

Key Words: Celiac disease; Crohn's disease; Gluten-sensitive enteropathy; Small intestinal biopsy; Specificity and sensitivity of serological tests; 'Sprue-like' intestinal disease; Tissue transglutaminase (tTG); Unclassified sprue

\section{Dosages très élevés d'anticorps antitransgluta- minase tissulaire, non associés à la maladie coeliaque}

La maladie coeliaque est une affection de l'intestin grêle, qui se caractérise par un aplatissement des villosités et une hyperplasie des cryptes et qui s'accompagne souvent de malabsorption. Elle se corrige par un régime exempt de gluten. Les dosages sensibles et spécifiques (p. ex. : les anticorps de type immunoglobuline A dirigés contre la transglutaminase tissulaire) susceptibles de quantification semblent de bons outils de dépistage dans la population. En outre, leur utilisation gagne de plus en plus de terrain en pratique clinique comme méthode de recherche de cas. Nous nous sommes penchés, dans la présente évaluation, sur l'utilisation clinique d'un nécessaire d'essai offert sur le marché. Sur 1330 prélèvements envoyés au laboratoire de notre hôpital par des médecins de la Colombie-Britannique, de l'Alberta et des Territoires du Nord-Ouest (entre 1999 et 2003 inclusivement), 96 (7\%) présentaient des valeurs élevées (plage normale supérieure à 20 unités) et $36(3 \%)$, des valeurs très élevées (supérieures à 100 unités). Quatorze patients (presque $40 \%$ ) ont été dirigés vers des gastro-entérologues de notre hôpital et tous ont été soumis à une biopsie de l'intestin grêle. De ce nombre, trois patients (plus de $20 \%$ ) ne souffraient pas de maladie coeliaque. Dans deux cas, la biopsie s'est révélée normale et dans l'autre cas elle a été associée à une sprue atypique ou à une entéropathie spruiforme, réfractaire au régime exempt de gluten. Dans les 11 autres cas, la biopsie a confirmé la présence de la maladie coeliaque. Alors, même si le dosage des anticorps antitransglutaminase tissulaire peut se montrer utile comme prédicteur de maladie coeliaque, il faut encore recourir à la biopsie de l'intestin grêle pour confirmer le diagnostic. En pratique clinique, même des dosages très élevés d'anticorps n'ont pas de spécificité chez les patients en particulier et ne correspondent pas nécessairement au degré de gravité de la maladie révélé par la biopsie; aussi est-il peu probable qu'on se serve des dosages comme outil de surveillance du respect du régime alimentaire.

\footnotetext{
$\mathrm{C}$ eliac disease is characterized by a small bowel lesion with 'flattened' villi and crypt hyperplasia, often associated with malabsorption. Biopsy findings normalize after the removal of dietary gluten, but mechanisms causing the disease have not been completely elucidated. Biopsy of the small bowel mucosa has been considered the diagnostic gold standard, but serological screening has also been used. Because endomysial antibodies are found in celiac disease, it was hypothesized that target antigen(s) in connective tissue may be critical in pathogenesis. Dieterich et al (1) identified tissue transglutaminase (tTG), an enzyme normally involved in wound repair, as the endomysial 'auto-antigen' of celiac disease, and suggested its
}

use to screen for celiac disease. Indeed, this has been widely applied (2-4), and the utility of an antibody assay in screening populations (eg, childhood insulin-dependent diabetes) for biopsy-defined celiac disease has been demonstrated in our own studies $(5,6)$.

A negative assay could result in cessation of studies for celiac disease although false-negative results have been noted, particularly if concomitant serum immunoglobulin (Ig) A deficiency is present $(7,8)$. For patients with a positive assay result, it has even been recently argued that, owing to the high degree of specificity and sensitivity of serological tests, small bowel biopsy might not be required (9). In recent years,

Department of Medicine (Gastroenterology), University of British Columbia, Vancouver, British Columbia

Correspondence: Dr Hugh Freeman, Gastroenterology, University of British Columbia Hospital, 2211 Wesbrook Mall, Vancouver,

British Columbia V6T 1W5. Telephone 604-822-7216, fax 604-822-7236

Received for publication August 8, 2003. Accepted October 21, 2003 
clinical laboratories have used commercially produced kits for tTG antibody testing. In this setting, biopsy correlation may be limited and 'local reliability' of the assay may not be known.

The present study reviewed biopsy results in patients seen by gastroenterologists in our hospital with marked elevations of tTG antibodies. Some had biopsy-defined celiac disease, but in others, celiac disease could not be confirmed. Commercially acquired test kits to serologically screen for celiac disease may be useful, but even a strongly positive assay should lead the clinician to seek small bowel biopsies to confirm the diagnosis of celiac disease.

\section{METHODS}

\section{Assay method and normal recorded range}

A commercial test kit assay (Quanta Lite tTG, Inova Diagnostics Inc, USA) has been used in our teaching hospital clinical laboratory (Vancouver Hospital and Health Sciences Centre) for serological quantitation of tTG antibodies since late 1999. This assay is a porcine-based (ie, guinea pig), enzyme-linked immunosorbent assay (ELISA) that quantifies IgA antibodies to the tTG enzyme in human serum. The normal recorded range provided by the supplier of the test kit is less than 20 units. The supplier also describes a weak positive (20 to 30 units), and moderate to strong positive (greater than 30 units). For the present evaluation, however, only strongly positive (greater than 100 units) assay results were used. In the product insert for this assay, the supplier describes a positive result in two of 202 normal samples, being weakly reactive at 21 and 24 units, respectively. The sensitivity of the commercial assay used here is $98.5 \%$ while the specificity is $94.1 \%$, comparable to a previously published 'in-house' human recombinant ELISA assay with a sensitivity of $98.5 \%$ and specificity of $95 \%$ (10) and a recombinant human ELISA assay (Pharmacia Diagnostics, Sweden) recently used to test stored sera from Finnish schoolchildren (11). This latter IgA anti-tTG assay was reported earlier by Hansson et al (12) to be positive in two of 53 control children. Finally, the assay also appears to be comparable to a novel rapid dot blot assay using human recombinant transglutaminase reported to have a sensitivity of $100 \%$, but positive in three of $64(4.7 \%)$ healthy controls (13).

\section{Usage of tTG antibody assay}

A total of 1330 assays were done (males, 731 assays [55\%]) from November 1999 to April 2003, inclusive, with the total annual number increasing for each calendar year. To date, this assay has not been restricted to any specific physician group and, as a result, serum samples have been received from British Columbia, Alberta and the Yukon Territory. Specialist gastroenterologists have been the largest single user group of this clinical laboratory test in our hospital (865 assays [over 65\%]).

\section{RESULTS}

Abnormal assays

Table 1 shows the number of normal and abnormal assays, including those quantitatively markedly elevated to greater than 100 units. In this series of assays, 96 of the assays (7\%) were abnormal. Of these, 60 were within the positive range (from 20 to 100 units). Markedly increased tTG antibody levels of greater than 100 units were present in the other 36 (approximately $3 \%$ ).

Of the 36 test results greater than 100 units, 14 (39\%) were requested by gastroenterologists in our hospital, and all of these
}

14 patients had endoscopic small intestinal biopsies to histologically define if celiac disease was present. Of these 14 patients, two had abnormal endoscopic changes reported, including 'scalloping' in one patient with histologically normal mucosa (14), while 12 were reported to show endoscopically normal-appearing small intestinal mucosa.

\section{Patients with tTG antibody levels greater than 100 units}

Table 2 summarizes the results of biopsy studies in these patients with a marked elevation (greater than 100 units). For a subsequent diagnosis of celiac disease, previously defined histological criteria were used (15), including the requirement for improvement on a gluten-free diet. In ome patient, a flat biopsy appearance was present in all biopsies despite a gluten-free diet and later treatments with corticosteroids and azathioprine. Although initially thought to be due to celiac disease, the failure to improve with a gluten-free diet is indicative of unclassified sprue $(15,16)$ or 'sprue-like' intestinal disease. This patient also had a prior proctocolectomy for severe colitis with ulcerations and granulomatous inflammation was evident histologically, typical of Crohn's disease of the colon. Possibly, these histological changes in the proximal small bowel mucosa represented involvement with Crohn's disease as described elsewhere (17). In two other patients in the present evaluation, the small intestinal biopsies were entirely normal with normal numbers of intraepithelial lymphocytes.

The first case was a 79-year-old woman initially evaluated in 1999 because of abdominal bloating, intermittent diarrhea and constipation. Investigations were normal, including gastroscopy and duodenal biopsies, and her symptoms were attributed to a dysfunctional bowel syndrome. In May 2002, a strongly positive sero-assay (over 100 units) led to a second normal gastroscopy along with a normal sigmoidoscopy. Biopsies of the stomach, duodenum and colon were normal. Previous biopsies were also reviewed by a gastrointestinal pathologist and confirmed to be normal.

The second case was a 42-year-old woman with reduced fertility and early menopause. In 1996, she was diagnosed with hypothyroidism after presentation with fatigue, and treatment consisted of thyroid replacement. In April 2002, osteopenic bone disease was detected. In June 2002, her 8 -year-old daughter was diagnosed with celiac disease after presentation with failure to thrive. She had no gastrointestinal symptoms or weight loss. She requested a 'celiac blood test' through her family physician and the test was strongly positive (greater than 100 units). A gastroscopy suggested 'scalloped' duodenal folds. However, duodenal and gastric biopsies were architecturally normal with no gastric or duodenal epithelial lymphocytosis.

Although biopsies were initially reported for clinical purposes by pathologists with special expertise in interpretation of gastrointestinal endoscopic biopsies, the author also personally reviewed biopsies from both patients and confirmed the normal reported findings. Intraepithelial lymphocytes were not increased and the villous to crypt ratios were normal.

\section{DISCUSSION}

Serological screening for celiac disease has become popular using either 'in-house' assays or commercially-produced test kits for antibodies to tTG, an intracellular enzyme that can be quantitatively measured in serum with a reported high sensitivity and specificity for celiac disease $(2,3)$. Unfortunately, the 
TABLE 1

\begin{tabular}{|c|c|c|c|c|c|}
\hline Assay range & 1999 & 2000 & 2001 & 2002 & 2003 \\
\hline Normal $^{*}$ & 9 & 291 & 304 & 453 & 177 \\
\hline Abnormal & 2 & 19 & 13 & 37 & 25 \\
\hline $20-60$ units & 0 & 8 & 8 & 18 & 13 \\
\hline $60-100$ units & 0 & 5 & 1 & 2 & 5 \\
\hline$>100$ units & 2 & 6 & 4 & 17 & 7 \\
\hline Total & 11 & 310 & 317 & 490 & 202 \\
\hline
\end{tabular}

${ }^{*}$ Reported normal range for $t T G$ assay is $0-20$ units

value of an 'in-house' assay may be geographically limited and the 'local reliability' of test kits used in most hospitals, including our own, is not known. Here, using a test kit, even marked tTG elevations, arbitrarily defined as a strongly positive antibody assay of greater than 100 units, were not indicative of celiac disease in three of 14 patients (over 20\%). Indeed, two of these patients had completely normal small intestinal biopsies with no increase in the numbers of intraepithelial lymphocytes. These findings show that even strongly positive seroassays for tTG antibodies did not define celiac disease and emphasizes that small intestinal biopsies are still required in clinical practice for a definitive diagnosis of this life-long disorder.

In screening populations for celiac disease, biopsies are usually done to confirm celiac disease in the sero-positive patient. In these studies, however, the rates of positive biopsies in seronegative cases are usually not addressed, because biopsies may be ethically difficult to perform. Even in our own research studies with stored serum (4), one patient with biopsy-defined celiac disease had normal tTG antibody levels. Indeed, as shown here in the evaluation of this commercially available seroassay, over $90 \%$ of patients had normal tTG antibody levels.

Even the specificity of a strongly positive tTG may be limited. In a patient with histological evidence of extensive Crohn's disease of the colon, flattened proximal small intestinal mucosa was repeatedly demonstrated despite multiple biopsies over many months on a gluten-free diet. There was also no histological change despite therapy with corticosteroids and azathioprine. Although some might label this as 'nonresponsive celiac disease', celiac disease should be initially diagnosed only if there is evidence of a diet response, not seen here. Instead, this patient had unclassified sprue $(15,16)$ or sprue-like intestinal disease. The cause(s) is not known, although it probably represents a heterogeneous group of disorders from a pathogenetic perspective (16). Alternatively, a severe 'flat' proximal small bowel mucosa, similar to untreated celiac disease, could represent Crohn's disease in the duodenum in this patient with colonic involvement (17).

Patients with celiac disease may have different tTG antibody levels, because this is a quantitative assay different from the more subjective semi-quantitative endomysial antibody test that is based on immunofluorescence methods. Indeed, in our own prior studies, the absolute tTG antibody levels varied by as much as 1000 -fold in untreated celiac disease (4). Correlation between tTG antibody level and degree of severity of mucosal injury has also been reported based on untreated and treated celiac disease biopsies (4). Higher mean levels of tTG were seen with most severe biopsy changes; however, the correlation between individual assay results and degree of
TABLE 2

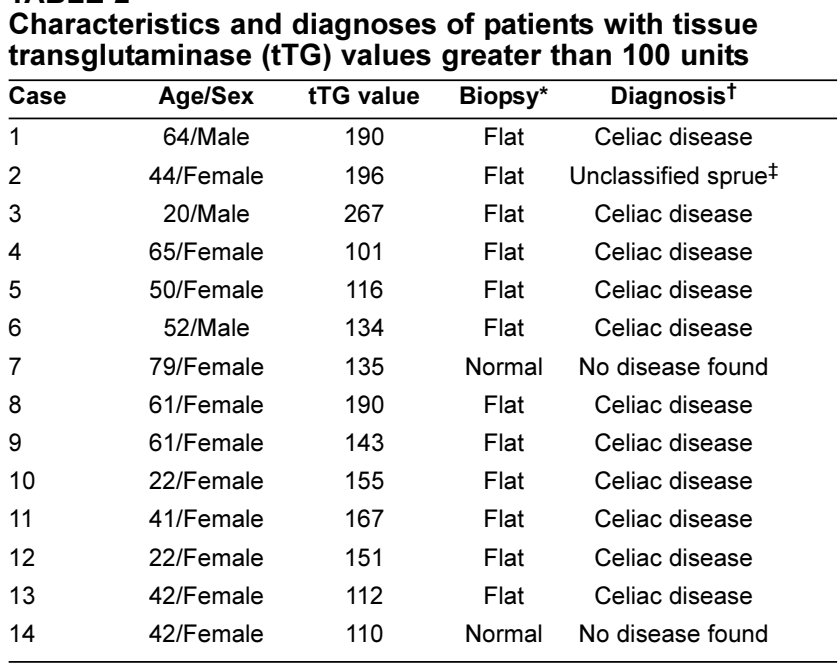

${ }^{*}$ Flat biopsy typical of untreated celiac disease ${ }^{\dagger}$ Celiac disease defined by biopsy and response to gluten-free diet. ¥Unclassified sprue or sprue-like intestinal disease with no histological response to gluten-free diet. See text and references 15 and 16

histological abnormality was limited with overlap even with normal biopsies. Similar findings have been reported from Europe (18). Although anti-tTG titers may fall with a glutenfree diet (4), others have suggested that serial measurements may provide a means of monitoring individuals for surreptitious or ubiquitous gluten ingestion (18-20). Based on the present clinical evaluation, the use of the tTG antibody assay in monitoring celiac disease for dietary compliance is not indicated, and could potentially provide a false sense of security for the clinician as well as the patient unaware of a ubiquitious gluten source.

Seroassays, specifically for tTG antibodies, initially utilized for population screening, have now become increasingly employed for celiac disease case finding. In this study, however, strongly positive tTG assays were not associated with celiac disease in over $20 \%$ of those evaluated by specialist adult gastroenterologists. Despite a strongly positive assay result, the tTG assay is not specific for biopsy-defined celiac disease, does not necessarily correlate with degree of mucosal damage in individual patients, and, as a result, has no clear value as an aid to monitor gluten-free diet compliance. The results of serological screening surveys for celiac disease require cautious translation to clinical use. Although they are very useful as predictors of celiac disease, diagnosis still requires biopsy definition.

\section{REFERENCES}

1. Dieterich W, Ehnis T, Bauer M, et al. Identification of tissue transglutaminase as the auto-antigen of celiac disease. Nature Medicine 1997;3:792-801.

2. Dieterich W, Laag E, Schopper H, et al. Autoantibodies to tissue transglutaminase as predictors of celiac disease. Gastroenterology 1998;115:1317-21.

3. Sulkanen S, Halttunen T, Laurila K, et al. Tissue transglutaminase autoantibody enzyme-linked immunosorbent assay in detecting celiac disease. Gastroenterology 1998;115:1322-8.

4. Gillett HR, Freeman HJ. Comparison of IgA endomysium antibody and $\operatorname{IgA}$ antibody to tissue transglutaminase in celiac disease. Can J Gastroenterol 2000;14:668-71. 
5. Gillett PM, Gillett HR, Israel DM, et al. Increased prevalence of celiac disease in girls with Turner's syndrome detected using antibodies to endomysium and tissue transglutaminase. Can J Gastroenterol 2000;14:915-8.

6. Gillett PM, Gillett HR, Israel DM, et al. High prevalence of celiac disease in patients with type 1 diabetes detected by antibodies to endomysium and tissue transglutaminase. Can J Gastroenterol 2001;15:297-301.

7. Cataldo F, Lio D, Marino V, Picarelli A, Ventura A, Corazza GR. IgG(1) antiendomysium and IgG antitissue transglutaminase (antitTG) antibodies in coeliac patients with selective IgA deficiency. Working Groups on Celiac Disease of SIGEP and Club del Tenue. Gut 2000;47:366-9.

8. Kumar V, Jarzabek-Chorzelska M, Sulej J, Karnewska K, Farrell T, Jablonska S. Celiac disease and immunoglobulin A deficiency: How effective are the serological methods of diagnosis? Clin Diagn Lab Immunol 2002; 9:1295-300.

9. Scoglio R, Di Pasquale G, Pagano G, Lucanto MC, Magazzu G, Sferlazzas C. Is intestinal biopsy always needed for diagnosis of celiac disease? Am J Gastroenterol 2003;98;1325-31.

10. Sblattero D, Berti I, Trevisiol C, et al. Human recombinant tissue transglutaminase ELISA: An innovative diagnostic assay for celiac disease. Am J Gastroenterol 2000;95:1253-7.

11. Maki M, Mustalahti K, Kokkonen J, et al. Prevalence of celiac disease among children in Finland. New Engl J Med 2003;348:2517-24.

12. Hansson T, Dahlbom I, Rogberg S, et al. Recombinant human tissue transglutaminase for diagnosis and follow-up of childhood celiac disease. Pediatr Res 2002;51:700-5.
13. Baldas V, Tommasini A, Trevisiol C, et al. Development of a novel rapid non-invasive screening test for celiac disease. Gut 2000;47:628-31.

14. Jabbari M, Wild G, Goresky CA, et al. Scalloped valvulae conniventes: an endoscopic marker of celiac sprue. Gastroenterology 1988;95:1518-22.

15. Freeman HJ. Small intestinal mucosal biopsy for investigation of diarrhea and malabsorption in adults. Gastroenterol Endo Clin North Am 2000;10:739-53.

16. Lewin KJ, Riddell RH, Weinstein WM. Small bowel mucosal disease. In: Gastrointestinal Pathology and its Clinical Implications. Tokyo: Igaku-Shoin, 1992:750-811.

17. Schuffler MD, Chaffee RG. Small intestinal biopsy in a patient with Crohn's disease of the duodenum. The spectrum of abnormal findings in the absence of granulomas. Gastroenterology 1979;76:1009-14.

18. Fabiani E, Catassi C, International Working Group. The serum IgA class anti-tissue transglutaminase antibodies in the diagnosis and follow up of coeliac disease. Results of an international multi-centre study. International Working Group on Eu-tTG. Eur J Gastroenterol Hepatol 2001;13:659-65.

19. Maki M, Sulkanen S, Collin P. Antibodies in relation to gluten intake. Dig Dis 1998;16:330-2.

20. Burgin-Woff A, Dahlbom I, Hadziselimovic F, Petersson CJ. Antibodies against human tissue transglutaminase and endomysium in diagnosing and monitoring coeliac disease. Scand J Gastroenterol 2002;37:685-91. 


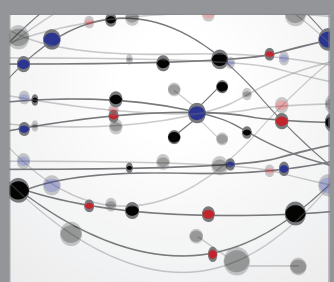

The Scientific World Journal
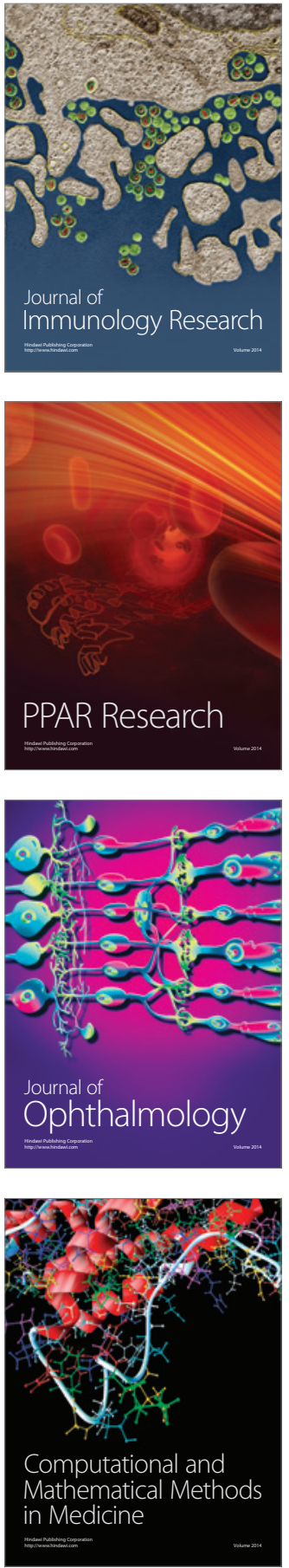

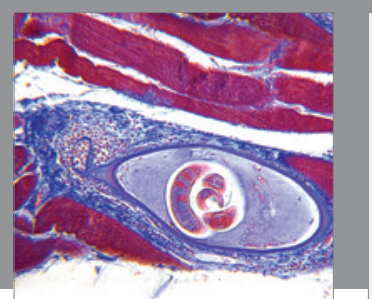

Gastroenterology Research and Practice

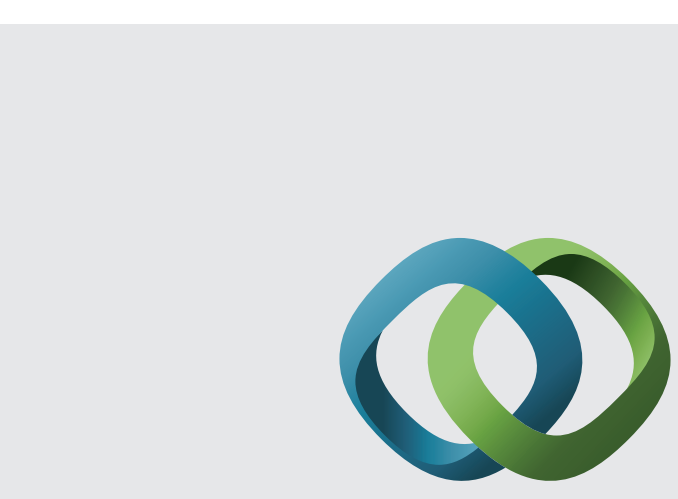

\section{Hindawi}

Submit your manuscripts at

http://www.hindawi.com
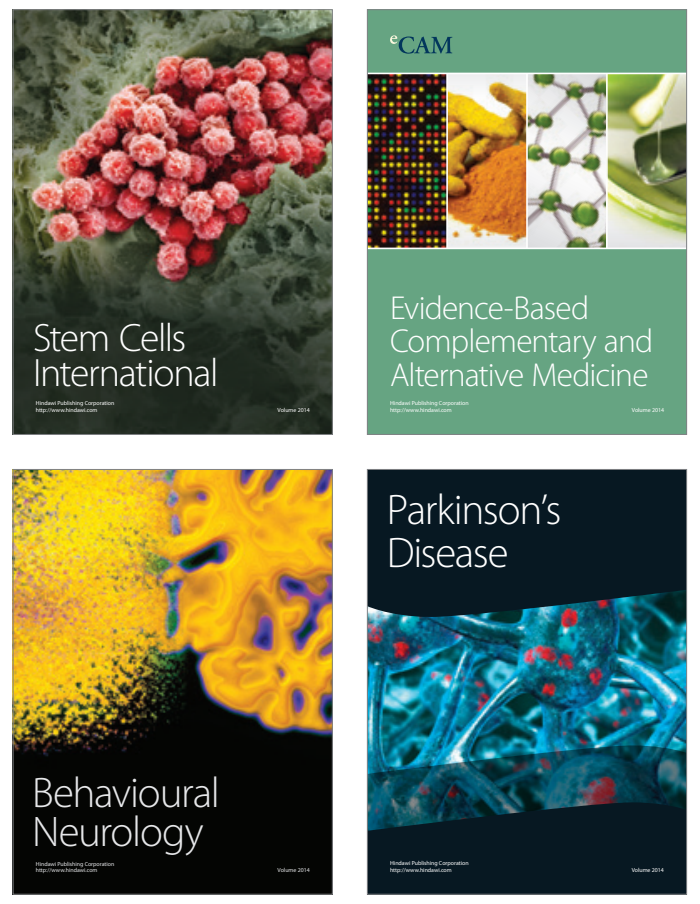
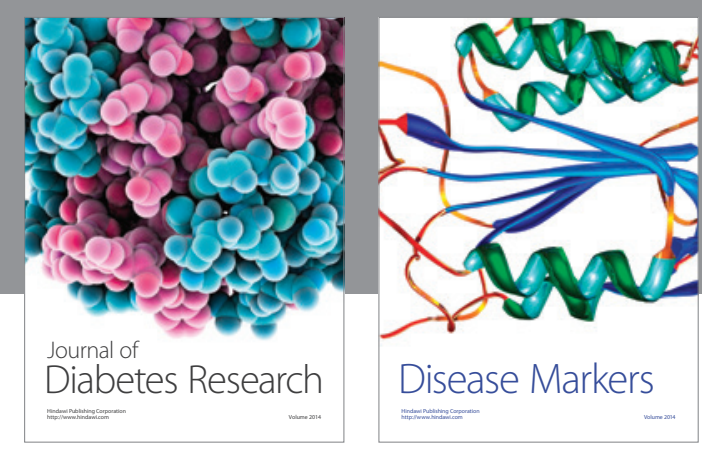

Disease Markers
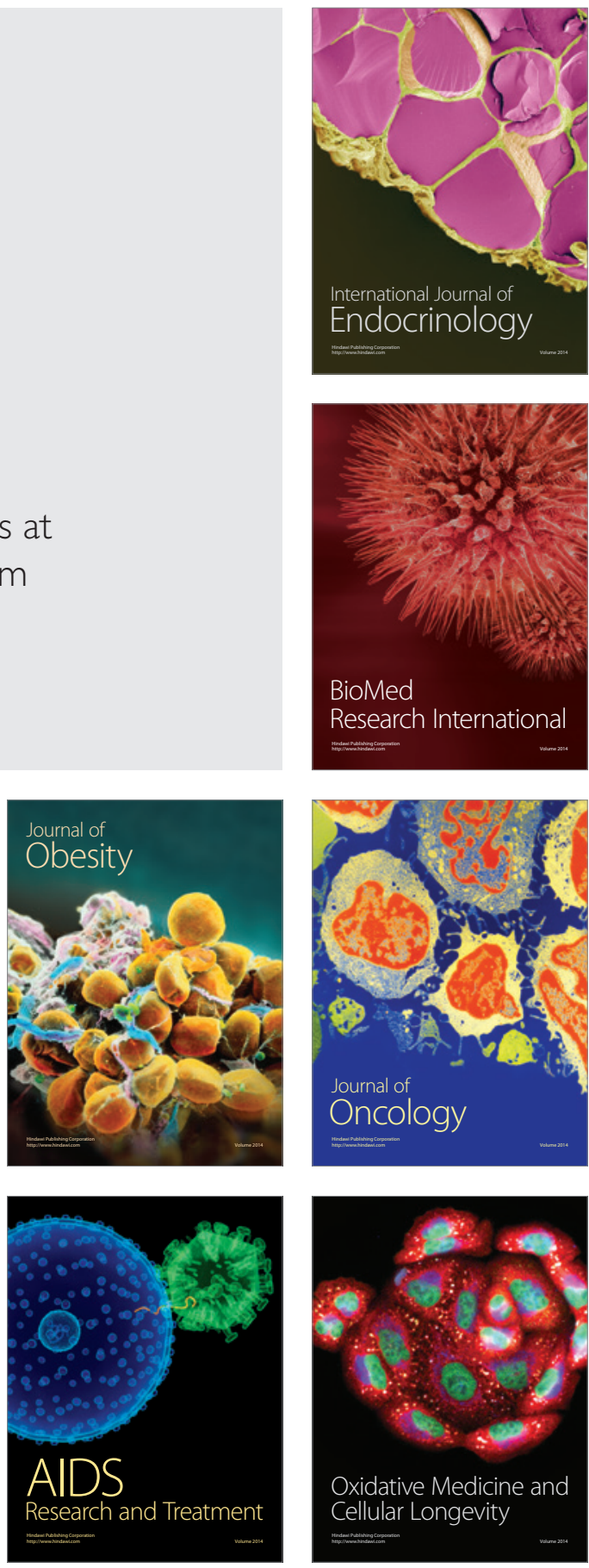